\author{
Anna Irena Szymańska \\ Uniwersytet Pedagogiczny \\ im. Komisji Edukacji Narodowej \\ w Krakowie
}

\title{
Globalizacja a nowe koncepcje zarządzania przedsiębiorstwem
}

Różnorodność rozwiązań proponowanych współcześnie przez zarządzanie, jak również gwałtowna globalizacja gospodarki, a w szczególności rewolucja w obszarze techniki i technologii informacyjnej, sprawiają, że zarządzanie przedsiębiorstwem XXI wieku musi być ukierunkowane na zewnętrzne otoczenie owego przedsiębiorstwa. Powinno ono polegać przede wszystkim na definiowaniu celów przedsiębiorstwa w kontekście potrzeb rynku i klienta. Natomiast zachodzące w skali globalnej procesy gospodarcze, polityczne i społeczne wymuszają konieczność reorganizacji wewnętrznej przedsiębiorstwa.

A. Toffler (1996), przedstawiciel nurtu tzw. nauki stosowanej, w swoich opracowaniach odwołujących się do technologii historię ludzkości rozpatruje przede wszystkim w kontekście trzech następujących po sobie fal technologicznych:

- agrarnej (rewolucja agrarna - odchodzenie od koczowniczego i upowszechnianie się osiadłego trybu życia, pojawienie się rolnictwa),

- przemysłowej (rewolucja przemysłowa na przełomie XVIII i XIX wieku, wynalezienie druku, maszyny parowej, pojawienie się industrializmu),

- związanej bezpośrednio z powstaniem nowych technologii pozwalających na nieograniczoną komunikację dzięki rozwojowi usług i odejście od masowej produkcji, powstanie społeczeństwa informacyjnego, społeczeństwa usługowego (rewolucja technologiczna).

Trzecia fala to epoka wiedzy i informacji. Sprzyja jej ogromne przyspieszenie rozwoju technologicznego przy jednoczesnej globalizacji i zaangażowaniu niemal wszystkich krajów w gospodarkę światową. Wiąże się ona z odchodzeniem od produkcji masowej na rzecz produkcji dostosowanej do potrzeb indywidualnego klienta. Człowiek przyszłości - prosument - łączy cechy producenta $\mathrm{i}$ konsumenta ${ }^{1}$.

\section{Globalizacja i jej istota}

Pojęciem globalizacja zazwyczaj określa się ogół procesów prowadzących do coraz większej współzależności i integracji państw, społeczeństw, gospodarek i kultur. Efektem tego jest tworzenie się ,jednego świata”, światowego społeczeństwa (Kempny 1998). W 1960 roku Marshall McLuhan wprowadził pojęcie globalna wioska, aby zilustrować kurczenie się świata będącego efektem wprowadzania nowych technologii komunikacyjnych. Globalizacja to autonomiczny, wielopłaszczyznowy i transgraniczny proces transformacji narodowych gospodarek, instytucji, społeczeństw i kultur w nowy, bardziej współzależny system. Brak jest jednak jednoznacznej

\footnotetext{
${ }^{1}$ Szerzej na ten temat zob.: Toffler 2006; Krawiec 2009; Dziedzic, Szymańska 2011.
} 
definicji globalizacji, ponieważ jest to proces wielowymiarowy i wielopoziomowy, który można analizować z wielu punktów widzenia (Liberska 2002). Ogólnie globalizacja oznacza nową jakość w procesie internacjonalizacji i postrzeganiu świata, w którym pojawiły się nowe rynki (np. globalne rynki finansowe), nowe narzędzia przekazu (np. przekaz elektroniczny), wielkie korporacje oraz globalne instytucje. Globalizacja gospodarki światowej stanowi proces poszerzania i pogłębiania się współzależności między krajami a regionami. Jest to efektem rosnących przepływów międzynarodowych, działania międzynarodowych korporacji oraz tworzenia się nowych powiązań między firmami, rynkami a gospodarkami (Liberska 2002). Aby globalna gospodarka mogła powstać i funkcjonować, konieczne są liberalne warunki rozwoju handlu międzynarodowego, inwestycje przedsiębiorstw oraz produkcyjno-handlowa działalność spółek zależnych.

Globalizacja dokonuje się w różnych dziedzinach życia. Według I. Czai, „globalizacja jako termin bardzo ogólny i pojemny oznacza zarówno rozpowszechnianie, powielanie i unifikację wzorów postępowania, akceptację postaw popularnonaukowych przez media, przenikanie elementów kulturowych, mieszanie się tych elementów, jak i szybkość, z jaką zachodzą te procesy dzięki zdobyczom techniki (rewolucji informatycznej)" (Czaja 2001, s. 65). Jest ona zjawiskiem ekonomicznym ze skutkami w sferze społecznej, kulturowej i politycznej, przejawiającym się w wielości powiązań i wzajemnych oddziaływań między państwami a społeczeństwami.

Analizując globalizację w ujęciu społecznym, można posłużyć się sposobem definiowania tego pojęcia przez angielskiego kulturoznawcę A. Giddensa. Definiuje on globalizację jako „intensyfikację stosunków społecznych o światowym zasięgu, która łączy różne lokalności w taki sposób, że lokalne wydarzenia kształtowane są przez zdarzenia zachodzące w odległości wielu tysięcy mil i same zwrotnie na nie oddziałują (Giddens 1999). Zgodnie z tym podejściem, globalizację należy rozumieć jako proces pokonujący zarówno bariery czasu, przestrzeni, jak i bariery społeczne. W efekcie owego procesu zachowania ludzi, społeczeństw i władzy z różnych obszarów oddziałują wzajemnie na siebie i ulegają pod swoim wpływem pewnym zmianom, tworząc tym samym kulturę globalną, na którą składają się różne elementy tradycji, kultury i wzorów zachowań.

Z pojęciem globalizacja mocno związane jest również pojęcie sektor globalny. Oznacza ono sektor, w którym strategiczna sytuacja konkurentów w ramach podstawowych ryków regionalnych lub krajowych w znacznym stopniu zależna jest od ich ogólnej sytuacji w skali światowej. W związku z powyższym sektory globalne wymagają od firm skoordynowanego konkurowania w skali światowej.

Podstawowymi czynnikami warunkującymi proces globalizacji są przede wszystkim:

- postęp techniczny, przyczyniający się do zwiększania ekonomii skali w produkcji,

- zmiana lub racjonalizacja kanałów dystrybucji, powstanie nowych rynków wykorzystujących informatyczne połączenia sieciowe, brak konieczności obecności bezpośredniej strony podażowej i popytowej,

- obniżenie kosztów transportu,

- zmniejszenie różnic ekonomicznych i społecznych między poszczególnymi krajami,

- złagodzenie ograniczeń państwowych (Porter 1992).

Zwolennicy globalizacji uważają, że jest ona efektem dokonującego się postępu naukowo-technologicznego i ogólnych tendencji rozwojowych. Dostrzegają w niej duże korzyści będące rezultatem:

- znoszenia ograniczeń w przepływie towarów, usług i kapitałów między państwami,

- zaistnienia możliwości pozyskiwania nowych rynków zbytu, 
- spadku kosztów związanych z transportem surowców wytwórczych,

- upadku nierentownych gałęzi przemysłu i zastąpieniem ich nowymi, nowoczesnymi liniami produkcyjnymi,

- redukcji kosztów na skutek minimalizowania liczby zatrudnionych (komputeryzacja, robotyzacja),

- powstawania transnarodowych korporacji i międzynarodowych instytucji finansowych,

- kreacją produktu globalnego, dostępnego w większości krajów na całym świecie.

Korzyści wynikające z procesu globalizacji są asymetrycznie rozłożone między krajami, sektorami i grupami społecznymi (Liberska 2001). W związku z powyższym możliwość zaistnienia na rynku globalnym wymusza na gospodarce narodowej każdego z krajów właściwe jej przystosowanie. Niezbędne jest stworzenie odpowiednich przepisów prawnych regulujących podejmowane przez rządy decyzje gospodarcze i polityczne. Przepisy te w szczególności powinny dotyczyć:

- polityki podatkowej,

- usług bankowych i ubezpieczeniowych,

- ochrony środowiska naturalnego,

- polityki wobec zagranicznych inwestorów, która słabszym przedsiębiorstwom pomogłaby przetrwać na rynku lokalnym, a jednocześnie stworzyłaby im szansę dalszego rozwoju,

- ochrony praw pracowników i konsumentów,

- dążeń danego kraju do zachowania tradycji, kultury, religii, języka narodowego i innych wartości.

Proces globalizacji daje olbrzymie możliwości rozwojowe przede wszystkim tym podmiotom gospodarczym, które potrafią się dostosować do zmieniających się warunków. W związku z tym kraje słabiej rozwinięte oraz przedsiębiorstwa i instytucje finansowe, które chcą zaistnieć na rynku globalnym, powinny korzystać z doświadczeń i skutecznych rozwiązań pochodzących z gospodarek państw wysoko rozwiniętych oraz korporacji transnarodowych.

Gwarancją prawidłowego rozwoju globalnego rynku jest odczuwalna konkurencyjność gospodarki. Nie może się ona opierać tylko na efektywności przedsiębiorstw, ale musi wystąpić spójna efektywność poszczególnych rynków, instytucji finansowych, przedsiębiorstw oraz jakości zasobów ludzkich i procesów innowacyjnych. Jedynie tak funkcjonująca gospodarka może przyciągnąć firmy zagraniczne i zwiększyć zakres globalnych powiązań.

Przeciwnicy globalizacji zwracają szczególną uwagę na zagrożenia przejawiające się głównie w:

- ograniczaniu roli państwa, a szczególnie opieki socjalnej,

- niszczeniu tradycji i podstawowych wartości, co prowadzi do utraty tożsamości narodowej,

- polityce wielkich korporacji transnarodowych polegającej na stałej redukcji kosztów, częstym nieprzestrzeganiu podstawowych praw pracownika oraz przepisów pracy,

- dewastacji środowiska naturalnego (Liberska 2001).

Proces globalizacji może prowadzić również do stopniowego ograniczenia autonomii poszczególnych krajów. Zmusza on rządy do podejmowania stosownych regulacji prawnych oraz decyzji gospodarczych i politycznych z zakresu polityki podatkowej, ubezpieczeniowej, bankowej, ochrony środowiska, polityki wobec zagranicznych inwestorów. Regulacje te są bezpośrednio związane z wydarzeniami lub też przemianami zachodzącymi na globalnych rynkach finansowych i towarowych. Globalizacja zmusza rządy krajów do śledzenia zmian i wprowadzania nowych rozwiązań, co pozwala na stopniowe eliminowanie nieopłacalnych gałęzi produkcji. W ich miejsce pojawiają się nowe, oparte na najnowszych technologiach, niestety niekoniecznie w kraju, w którym dana branża upadła. Naukowcy z Grupy Lizbońskiej twierdzą, 
iż w wyniku postępującej rewolucji technologicznej, a także stopniowego zaniku roli państwa opiekuńczego będzie wzrastało bezrobocie na całym świecie. Kryzys ten dotknąć może także kraje wysoko rozwinięte, gdyż wzrost gospodarczy nie musi oznaczać wzrostu zatrudnienia. Natomiast rewolucja naukowo-technologiczna, występująca w coraz większej liczbie sektorów gospodarek narodowych, uniemożliwi kompensowanie utraconych miejsc pracy w danych branżach przez ich przyrost w innych (Grupa Lizbońska 1996).

\section{Podstawowe korzyści i zagrożenia płynące z globalizacji}

Konsekwencją globalizacji jest tworzenie się ogólnoświatowej gospodarki. Jest to możliwe dzięki usuwaniu barier granicznych, likwidacji narzędzi oraz sposobów ochrony przed konkurencją zewnętrzną, uwalnianiu rynku od ograniczeń narzucanych przez państwo. Przejawem globalizacji jest ,przestrzenna reorganizacja produkcji i penetracja przemysłów poprzez granice, powiązania rynków finansowych, dyfuzja technologii i upodobnianie się norm, standardów wytwarzania oraz stylów konsumpcji na całym świecie” (Mittelman 1996). Globalizacja jest więc siłą napędzającą zarówno przemiany ekonomiczne, polityczne, jak i społeczne. Z drugiej jednak strony stanowi ona poważny wstrząs dla gospodarek poszczególnych krajów, ich społeczeństw i gospodarki światowej. Globalizacja niesie ze sobą ogromne szanse na rozwój, ale i poważne zagrożenia (tab. 1).

Tab. 1. Korzyści i zagrożenia związane z globalizacją

\begin{tabular}{|c|c|}
\hline Korzyści płynące z globalizacji & Zagrożenia związane z globalizacją \\
\hline $\begin{array}{l}\text { Zbliża odległe kulturowo i geograficznie kraje } \\
\text { Sprzyja wymianie informacji, myśli i pomysłów } \\
\text { Wspomaga upowszechnianie lepszych, wydaj- } \\
\text { niejszych, energooszczędnych i ekologicznych } \\
\text { technologii } \\
\text { Przyspiesza transfer czynników rozwojowych } \\
\text { Promuje konkurencję } \\
\text { Wymusza innowacyjność } \\
\text { Zwiększa inwestycje w atrakcyjnych ekonomicz- } \\
\text { nie regionach } \\
\text { Upowszechnia wiedzę } \\
\text { Aktywizuje gospodarczo kraje - beneficjentów } \\
\text { bezpośrednich inwestycji } \\
\text { Integruje i tworzy płaszczyznę do współpracy } \\
\text { ludzi z odrębnych obszarów kulturowych } \\
\text { Wzmacnia procesy demokratyzacji }\end{array}$ & $\begin{array}{l}\text { Oznacza ekspansję gospodarczą korporacji } \\
\text { międzynarodowych i ponadnarodowych } \\
\text { Uniemożliwia kontrolę nad korporacjami, } \\
\text { które kierują się własną logiką ekonomiczną } \\
\text { Osłabia pozycję państwa i wymusza tworzenie } \\
\text { warunków sprzyjających inwestowaniu } \\
\text { i zatrzymywaniu kapitału korporacji } \\
\text { Osłabia rolę państwa w krajach zacofanych } \\
\text { Upowszechnia obce kulturowo wzory } \\
\text { Multiplikuje kultury organizacji ponadnarodowych } \\
\text { korporacji } \\
\text { Czasowo wykorzystuje czynniki ekonomiczne } \\
\text { (niskie płace, niskie ceny surowców i nośników } \\
\text { energii, uwarunkowania prawne i podatkowe) } \\
\text { Utrudnia nadzorowanie korporacji przez instytucje } \\
\text { kontrolne państw, w których rezydują, poprzez } \\
\text { stosowanie własnych wewnętrznych systemów } \\
\text { organizacji pracy } \\
\text { Oznacza intensywny proces powiązań produkcyj- } \\
\text { nych, dystrybucyjnych, informacyjnych, finanso- } \\
\text { wych i kapitałowych tworzonych i kontrolowanych } \\
\text { tylko przez korporacje na rynku światowym }\end{array}$ \\
\hline
\end{tabular}

Źródło: Czaja 2006, s. 16. 
Globalizacja, powiązana bezpośrednio z dążeniem do stworzenia świata pozbawionego granic gospodarczych, społecznych, kulturowych czy informacyjnych, jest procesem obiektywnym, w którym kraje muszą nauczyć się funkcjonować i zgodnie z jego regułami rozwijać swoją działalność. W związku z powyższym państwa winny prowadzić politykę, która będzie nastawiona na minimalizację zagrożeń gospodarczych i zwiększanie korzyści płynących z globalizacji.

\section{Globalizacja a zarządzanie}

Zmiany obserwowane obecnie w gospodarce światowej przyczyniają się do nowego spojrzenia na różne aspekty funkcjonowania przedsiębiorstwa w gospodarce. Do owych przemian, określanych mianem światowych trendów rozwoju, należą przede wszystkim:

- globalizacja gospodarki światowej i związany z nią wzrost liczby powiązań gospodarczych między poszczególnymi krajami, przedsiębiorstwami;

- ograniczenie niezależności gospodarczej państw będące efektem spadku znaczenia wpływu granic na działalność handlową, a co za tym idzie - swoboda przepływu kapitału, techniki, dóbr, ludzi, usług, informacji, a w efekcie również idei, poglądów, koncepcji intelektualnych i stylów zarządzania;

- aktywizacja i dążenie do internacjonalizacji działania małych i średnich przedsiębiorstw poprzez wykorzystanie innowacyjności, operatywności i dużej zdolności adaptacyjnej do zmieniających się warunków działania;

- powstanie jednolitego rynku, na którym przestaną istnieć bariery i ukształtują się nowe relacje gospodarcze, nastąpi wzrost konkurencji międzynarodowej, czynnikiem warunkującym zmiany w sytuacji rynkowej będą nowe technologie przyspieszające tempo innowacji oraz proces ich weryfikacji na rynku, spadnie rola ceny, a wzrośnie znaczenie totalnej jakości i agresywnego marketingu;

- zmiana stylów życia, będąca konsekwencją starzenia się społeczeństw, zmiany systemów wartości, gustów i upodobań oraz rosnącej roli zdrowego środowiska w podnoszeniu jakości życia;

- konieczność upodmiotowienia pracowników poprzez stwarzanie im możliwości rozwoju zawodowego, partycypacji w korzyściach związanych z rozwojem przedsiębiorstwa poprzez podnoszenie wagi ich pracy oraz poprawę warunków pracy;

- rosnąca liczba możliwych alternatyw wyboru zawodu oraz miejsca pracy, wzrost oczekiwań i aspiracji tzw. ludzi nowych wartości jako lepiej wykształconych i oczekujących szybszych karier zawodowych;

- wydłużanie horyzontu czasowego niezbędnego w procesie podejmowania decyzji gospodarczych oraz wzrost czynnika czasu w walce konkurencyjnej i zaspokajaniu potrzeb rynku;

- głęboki i nieodwracalny w skutkach kryzys hierarchicznych struktur zarządzania, szybka decentralizacja organizacji i hierarchii, powstawanie sieci przetwarzania informacji, a także zasadnicze zmiany w strukturze zarządzania;

- pełniejsza transformacja gospodarki industrialnej w gospodarkę informacyjną, szeroki przepływ informacji, ułatwiający nawiązywanie stosunków handlowo-produkcyjnych, tworzenie wspólnych przedsiębiorstw, zdobywanie nowych segmentów rynku, tworzenie nowych sieci sprzedaży i produkowanie wyrobów dostosowanych do potrzeb lokalnych rynków zagranicznych niezależnie od ich położenia geograficznego (Penc 2002).

Opisane powyżej przemiany w znacznym stopniu oddziaływają na sferę zarządzania, mają one również dominujące znaczenie w kształtowaniu się nowoczesnych koncepcji zarządzania 
przedsiębiorstwem. Owe nowoczesne zarządzanie musi umożliwić przedsiębiorstwu elastyczne reagowanie na zmienność warunków, w jakich przychodzi mu funkcjonować, jak również dużą mobilność i przedsiębiorczość w podejmowaniu ryzykownych decyzji. Jest to podyktowane przede wszystkim koniecznością zapewnienia przewagi konkurencyjnej, satysfakcji odbiorców oraz osiągnięcia innych celów wynikających z przedmiotu działalności przedsiębiorstwa.

Zdaniem P.F. Druckera (Drucker 2000), efektywne zarządzanie przedsiębiorstwem XXI wieku opiera się na nowych paradygmatach oraz racjonalnych instrumentach zarządzania. Istotą owych paradygmatów zarządzania jest odejście od schematyzmu, uznanie gwałtownej dynamiki zmian otoczenia przedsiębiorstwa oraz różnorodności warunków funkcjonowania przedsiębiorstw. Przedsiębiorstwa muszą wykazywać się większą otwartością na technologię, a także innowacyjnością, przedsiębiorczością, zdolnościami adaptacyjnymi.

\section{Współczesne koncepcje i metody zarządzania przedsiębiorstwem}

Obserwowane współcześnie przemiany gospodarcze i społeczne, postępująca globalizacja i unifikacja rynku wymuszają nowoczesne zarządzanie przedsiębiorstwem. Wdrażanie nowoczesnych koncepcji zarządzania umożliwia zapobieganie zagrożeniom lub też wykorzystanie niespodziewanie pojawiających się szans. W działalności gospodarczej obserwuje się wiele różnorodnych koncepcji zarządzania przedsiębiorstwem. O wyborze jednej z nich lub pewnej zintegrowanej orientacji przesądzają zazwyczaj zdolności kadry menedżerskiej owego przedsiębiorstwa do przewidywania następstw zastosowania wybranych rozwiązań. Najczęściej stosowane obecnie koncepcje zarządzania przedsiębiorstwem to:

1. Koncepcje zorientowane na proces zarządzania przedsiębiorstwem:

- marketing - orientacja na rynek i klienta,

- logistyka - zarządzanie całym łańcuchem dostaw materiałowych, a w jej ramach just-in-time production i just-in-time management - wytwarzanie i zorganizowanie wszelkiej działalności ,akurat na czas”,

- human resources management - humanizacja pracy i orientacja na pracę zespołową,

- TQM (total quality management) - kompleksowa kontrola jakości,

- controlling - integracja łańcucha tworzenia wartości,

- time based management (TBM) - zarządzanie czynnikiem czasu,

- benchmarking - analiza porównawcza,

- outsourcing - orientacja na zaopatrzenie;

2. zorientowane przede wszystkim na zarządzanie zmianami ${ }^{2}$ :

- lean management - „odchudzone” zarządzanie,

- business process reengineering (reengineering) - radykalne przeprojektowanie procesów,

3. zorientowane na formy organizacji - organizacja ucząca się, inteligentna, sieciowa, wirtualna.

Wymienione powyżej koncepcje różnią się przede wszystkim podejściem do czynników gospodarowania oraz zróżnicowanymi zaleceniami co do zarządzania przedsiębiorstwem i wprowadzania zmian.

\footnotetext{
${ }^{2}$ Koncepcja business process reengineering zakłada podejście rewolucyjne (radykalne i szybkie zmiany), koncepcja lean management natomiast - podejście ewolucyjne (mniej radykalne, powolne i systematyczne wprowadzanie zmian).
} 


\section{Benchmarking}

W literaturze przedmiotu odnaleźć można wiele sposobów definiowania pojęcia benchmarking. I tak na przykład Z. Martyniak w swojej publikacji przytacza kilka definicji benchmarkingu:

- uczenie się od najlepszych przez porównywanie się z nimi,

- poszukiwanie najefektywniejszych metod dla danej działalności, pozwalających osiągnąć

- przewagę konkurencyjną,

- porównywanie procesów, produktów i usług z ich odpowiednikami u najlepszych konkurentów,

- ciągła ocena produktów, usług i metod danego przedsiębiorstwa w świetle osiągnięć konkurentów lub liderów w danej branży,

- poszukiwanie wzorcowych sposobów postępowania przez uczenie się od innych i wykorzystywanie ich doświadczenia (Martyniak 1996; Zimniewicz 2009).

Benchmarking może mieć charakter: strategiczny (porównywanie przedsiębiorstwa z liderami w swojej branży), proceduralny (porównywanie z przedsiębiorstwami wiodącymi w różnych obszarach działalności gospodarczej) lub marketingowy (regularne badania opinii klientów dotyczących jakości i istotnych cech wytwarzanych towarów oraz zestawianie ich z opiniami o wyrobach przedsiębiorstw konkurencyjnych). Natomiast przedmiotem porównań mogą być całe przedsiębiorstwa (struktura, miejsca pracy, produkty), jak również poszczególne elementy działalności organizacyjnej przedsiębiorstw (aktywność współpracowników, megaprocesy). Benchmarking jest więc bardzo szerokim pojęciem, pozwalającym na porównywanie wytwarzanych produktów, świadczonych usług, stosowanych metod i procesów.

Metodykę benchmarkingu tworzy kilka kluczowych etapów postępowania (Zimniewicz 2009). Są to:

- wyznaczenie obiektu benchmarkingu,

- analiza wewnętrzna,

- wyznaczenie partnera,

- analiza partnera,

- ocena wyników,

- planowanie i realizacja zmian oraz doskonalenie.

W pierwszej kolejności wyznacza się obiekt benchmarkingu. Etap ten wiąże się przede wszystkim z określeniem przedmiotu analizy. Po dokonaniu wyboru obiektu badania koniecznym jest wyodrębnienie i przeanalizowanie czynników, które wpływają na wzrost efektywności usprawnianych procesów, a w efekcie na podniesienie poziomu zadowolenia klienta. Niezbędnym jest również powołanie zespołu badawczego, którego członkowie winni posiadać wiedzę stosowną do przedmiotu analizy, jak również odpowiedni autorytet oraz wolę przeprowadzenia zmiany (Zimniewicz 2009; Karlöf, Östblom 1995).

$\mathrm{Na}$ etapie analizy wewnętrznej dokonuje się szczegółowej charakterystyki obiektu benchmarkingu. Wyniki owej charakterystyki wykorzystywane są do formułowania wniosków o sposobie modyfikacji lub optymalizacji przedmiotu badania (np. produktu czy struktury przedsiębiorstwa). Uzyskane w ten sposób informacje ułatwiają poszukiwanie odpowiedniego partnera i opracowanie listy pytań (np. o wewnętrzną organizację przedsiębiorstwa), na które odpowiedzi należy szukać w czasie dalszej analizy.

Kolejnym etapem jest wyznaczenie partnera benchmarkingu, który mógłby być wzorcem lub punktem odniesienia. Analiza partnera ma kluczowe znaczenie w metodyce benchmarkingu, ponieważ umożliwia poznanie różnic występujących między praktyką innych firm a praktyką własną oraz uzyskanie odpowiedzi na pytania postawione w poprzednim etapie. 
Piąty etap to ocena wyników, czyli ocena pozyskanych informacji. Ten etap metody benchmarkingu umożliwia identyfikację warunków, których spełnienie pozwoliło partnerowi na osiągnięcie pozycji lidera na rynku.

Ostatni etap to implementacja zmian i doskonalenie. Punktem wyjścia jest tutaj wyznaczenie osób odpowiedzialnych za opracowanie projektu zmian, przygotowanie harmonogramu wdrożenia projektu oraz przedstawienie listy środków niezbędnych do realizacji usprawnienia i metod motywacji pracowników.

Benchmarking jest to narzędzie służące przede wszystkim do podnoszenia efektywności operacyjnej przedsiębiorstwa. Nie powinno się natomiast stosować benchmarkingu na poziomie strategicznym, gdyż może to doprowadzić do zniszczenia branży.

\section{Lean management}

Lean management, podobnie jak reengineering, benchmarking czy outsorsing, zaliczany jest do rodziny nowych koncepcji zarządzania. Oznacza 'odchudzone, wyszczuplone, wysmuklone zarządzanie', w którym pierwszoplanową rolę odgrywa pracownik. Wywodzi się on z lean production ('odchudzonej produkcji'), koncepcji zastosowanej po raz pierwszy w japońskim koncernie samochodowym Toyota. Istotą koncepcji lean management jest uzyskanie wysokiej wydajności produkcji i pracy, sprawnej organizacji i zarządzania, wysokiej jakości produkcji i usług oraz satysfakcjonujących wyników ekonomicznych w celu dostosowania przedsiębiorstwa do aktualnych, rynkowych warunków gospodarowania. Osiągnięcie tych celów możliwe jest poprzez dokonanie integracji celów, zadań i funkcji przedsiębiorstwa. Kluczowym celem omawianej koncepcji jest dostosowanie przedsiębiorstwa do aktualnych, rynkowych warunków gospodarowania poprzez przeprowadzenie gruntownych przekształceń organizacji oraz metod zarządzania i funkcjonowania.

W szerszym znaczeniu koncepcja lean management postrzegana jest jako tworzenie nowej i bardziej efektywnej organizacji (w tym również produkcji). Działania te oparte są na filozofii lean thinking i polegają na wykorzystaniu nowych, ale sprawdzonych w praktyce osiągnięć nauki i techniki, w celu zapewnienia przedsiębiorstwu wysokiego poziomu konkurencyjności oraz właściwej jakości i satysfakcji klienta. Koncepcja ta może być alternatywą filozofii TQM czy reengineeringu. Koncentruje się ona na eliminacji marnotrawstwa oraz obniżaniu kosztów działalności we wszystkich obszarach działalności firmy. W tym celu konieczna jest odpowiedź na pytanie o to, co stanowi właściwą wartość dodaną dla klienta, oraz skoncentrowanie się właśnie na tych obszarach działalności. Istotne jest również kreowanie kultury wysokiej jakości, permanentnego usprawniania procesów i organizacji, identyfikacja pracowników z celami przedsiębiorstwa oraz zaangażowanie wszystkich członków organizacji w rozwój firmy (Czerska 2002).

Do podstawowych zasad lean management należy zaliczyć:

- efektywne wykorzystanie kadr,

- stosowanie metod zarządzania jakością i Total Quality Control,

- stosowanie zarządzania logistycznego,

- rynkowy charakter produkcji,

- koncentrację na działaniach podstawowych,

- permanentną realizację przedsięwzięć innowacyjnych,

- eliminację marnotrawstwa ( $m u d a)$,

- dobre zarządzanie zasobami ludzkimi,

- elastyczność, odchudzanie i spłaszczanie struktur organizacyjnych,

- zdecentralizowany i sprawny system informacji, 
- stosowanie nowej technologii FMS,

- efektywne wykorzystanie czasu,

- nastawienie całej załogi firmy na totalne ograniczanie zbędnych kosztów i działań (Nogalski, Walentynowicz 2004).

Koncepcja lean management może być stosowana zarówno w organizacjach o uwarunkowaniach stabilnych (strukturach funkcjonalnych), jak i w organizacjach o uwarunkowaniach dynamicznych (strukturach procesowych).

\section{Outsourcing}

Outsourcing to koncepcja zarządzania polegająca na powierzeniu realizacji pewnych funkcji przedsiębiorstwa partnerom zewnętrznym. Zastosowanie tej koncepcji wynika z nowego spojrzenia na funkcję zaopatrzenia oraz na działalność usługową prowadzoną w przedsiębiorstwie. Wiąże się ono z koncentracją na kluczowych obszarach działania firmy. Istotą koncepcji jest więc odchudzenie dotychczasowej struktury organizacyjnej (koncepcja spin off), obniżenie kosztów stałych, wyeliminowanie działań, które nie generują wartości dodanej. Umożliwia to lepsze pełnienie przez wyspecjalizowane firmy określonych funkcji dotąd realizowanych przez przedsiębiorstwo.

W każdym wypadku podstawową przesłanką wdrażania w przedsiębiorstwie outsourcingu winna być redukcja całkowitych kosztów generowanych przez określoną funkcję przedsiębiorstwa. Należy tu również brać pod uwagę takie aspekty, jak:

- związek z działalnością podstawową (aby nie tracić lub nie wyprowadzać na zewnątrz informacji o kluczowych przewagach konkurencyjnych),

- ryzyko utraty informacji,

- ryzyko obniżenia sprawności działalności podstawowej (outsourcing/insourcing),

- jakość i złożoność usług,

- dywersyfikacja ryzyka rynkowego,

- dodatkowe korzyści z tytułu zaangażowania wolnych środków inwestycyjnych w inną działalność biznesową (koszty alternatywny) (Nogalski, Walentynowicz 2004).

Zazwyczaj wymienia się następujące rodzaje outsourcingu: kontraktowy (organizacja niezwiązana kapitałowo); kapitałowy (organizacje związane kapitałowo - małe grupy holdingowe); działalności podstawowej (części, podzespoły, podwykonawcy itd.); działalności pomocniczej (utrzymanie ruchu, transport, B+R, magazynowanie itp.); działalności funkcjonalnej (konsulting, księgowość, marketing, handel, kadry itp.); działalności obsługi (administracja, sprzątanie, ochrona, stołówki, informatyka itp.) (Nogalski, Walentynowicz 2004).

Podstawą podjęcia decyzji o implementacji outsourcingu powinien być bilans kosztów całkowitych i korzyści wynikających z wdrożenia określonej funkcji outsourcingu oraz pozostania przy tradycyjnym rozwiązaniu. Z punktu widzenia charakterystyki współczesnego rynku jest to koncepcja najszerzej stosowana, przynosząca dużo korzyści oraz najbardziej komplementarna w stosunku do innych koncepcji ${ }^{3}$.

\section{Reengineering (Business Process Reengineering)}

„Istota reengineeringu polega na fundamentalnym, radykalnym i dramatycznym zburzeniu starych struktur i procesów w organizacji i zbudowaniu ich od nowa przy wykorzystaniu posiadanych i odzyskanych zasobów oraz nowoczesnych technologii informatycznych" (Lipiec 1996; Hammer 1996). Reengineering to nowa koncepcja modelu przedsiębiorstwa, której

\footnotetext{
$\overline{3}$ Koncepcja ta jest szeroko opisywana m.in. w takich źródłach, jak: Trocki 2001; Zimniewicz 2009, Zarządzanie 2000.
} 
podstawowym celem jest całkowita przebudowa organizacji oraz przeprojektowanie realizowanych przez nią procesów. Efektem owych radykalnych przemian mają być duże oszczędności zarówno w obszarze jakości, jak i serwisu, kosztów itp. Główne wytyczne kierunków implementacji koncepcji reengineeringu to:

- zmiana jednostek organizacyjnych - od działów funkcjonalnych do zespołów procesowych,

- zmiana stanowisk pracy - od wyspecjalizowanych do wielowymiarowych (job enrichment) lub uniwersalnych (job entlargement),

- zmiana stanowisk z kontrolowanych w kierunku stanowisk dających pełnię władzy i samokontrolę,

- przejście od szkolenia do edukacji,

- przesunięcie tradycyjnych miar wydajności i wynagradzania z działania na efekty działania,

- zmiana kryteriów awansu - od wydajności do kompetencji i zdolności,

- zmiana wartości i koncepcji myślenia - od ochronnych i stabilnych do produktywnych i prorozwojowych,

- zmiana roli menedżerów - od nadzorców do doradców,

- zmiana struktur organizacyjnych - od funkcji do procesów, od hierarchii do równości,

- zmiana roli zarządzających - od podliczania punktów do przewodzenia i myślenia strategicznego (Nogalski, Walentynowicz 2004).

W praktyce wdrożenie koncepcji reengineeringu wiąże się przede wszystkim z zastosowaniem nowoczesnej technologii FMS (Flexible Manufacturing Systems), kompleksowych, nowoczesnych systemów informatycznych (Computer Aided Manufacturing - CAM, Computer Integrated Manufacturing - CIM, Manufacturing Resource Planing - MRPII, Enterprise Resource Planing - ERP), jak również reorganizacja kultury organizacyjnej przedsiębiorstwa (Nogalski, Walentynowicz 2004). Niestety, jest to związane z dużymi nakładami kapitałowymi.

Wdrożenie koncepcji reengreeingu przynosi przedsiębiorstwu podwójną korzyść. Z jednej strony następuje wyeliminowanie przestarzałych i nieefektywnych metod gospodarowania i zarządzania, a z drugiej strony - utrzymanie dotychczasowej pozycji na rynku.

Koncepcja reengineeringu wprowadziła nowe spojrzenie na organizację. Literatura przedmiotu dysponuje wieloma przykładami przedsiębiorstw, w przypadku których wdrożenie koncepcji reengineeringu zakończyło się powodzeniem, np. firma ABB, która skróciła o 1/2 czas wprowadzania na rynek nowych wyrobów, CIBA-GEIGY, która zwiększyła o 5\% swoje obroty, Rank - Xerox, która skróciła realizację swoich zamówień z 33 dni do 6 dni (Martyniak 1998). Twórcy koncepcji, M. Hammer i J. Campy, opisują osiągnięcia firm, takich jak: Hallmark, Taco Bell, Capital Holding i Bell Atlantic.

Odnaleźć można jednak również przykłady przedsiębiorstw, w przypadku których zastosowanie reengineeringu nie przyniosło spodziewanej poprawy działania, zaś niektóre organizacje zmuszone były nawet do szybkiego wycofania się z wdrażania tej koncepcji. W przeważającej części przypadków zawiódł czynnik ludzki. Rewolucyjne wprowadzanie zmian zazwyczaj wywołuje opór wśród pracowników przedsiębiorstwa. Wdrożenie nowego sposobu myślenia wymaga szczególnych zdolności przywódczych u menedżerów. Kolejnym czynnikiem, który zdecydowanie ogranicza wprowadzanie reengineeringu, może okazać się przesunięte w czasie pojawianie się pierwszych pozytywnych rezultatów wprowadzonych zmian. Może to wpłynąć na wycofanie się z kontynuowania implementacji reengineeringu niecierpliwych zwolenników tej metody.

Wdrożenie reengineeringu bezpośrednio wiąże się z wykorzystaniem w przedsiębiorstwach technologii informatycznej (wdrażanie zintegrowanych systemów zarządzania klasy ERP). Istotnym jest jednak, aby było to poprzedzone restrukturyzacją procesów prowadzonych 
w przedsiębiorstwie. W przeciwnym wypadku zastosowanie tych narzędzi może nie przynieść oczekiwanych efektów. Prawdziwa siła technologii nie tkwi bowiem w usprawnianiu funkcjonowania starych procesów, ale w umożliwieniu przedsiębiorstwom zerwania ze starymi regułami i tworzeniu nowych sposobów wykonywania pracy (Hammer, Champy 1996).

\section{Kompleksowe zarządzanie przez jakość - TQM (Total Quality Management)}

Total Quality Management oznacza zarząadzanie przez jakość totalną (Pawlak 2004). Jest to metoda innowacyjnego podejścia do zarządzania organizacją, promująca budowanie kompleksowej, indywidualnej kultury organizacyjnej przedsiębiorstwa na gruncie wspólnych celów i wartości. Realizacja założeń konkurencyjnego przedsiębiorstwa odbywa się tu na podstawie specyficznego kodu zadań, w którym jakość stanowi kluczowy element spajający wszystkie sfery funkcjonowania organizacji. Zachodzące w przedsiębiorstwie procesy i szeroko pojęty kapitał zakładowy tworzą swoistą mapę funkcjonalną firmy.

Porównując poglądy najważniejszych teoretyków i praktyków zajmujących się koncepcją zarządzania przez jakość, można odnaleźć pewne podobieństwa (Karaszewski 1999). Są to:

- pełne zaangażowanie najwyższego kierownictwa jest warunkiem koniecznym,

- praktykowanie zarządzania jakością oszczędzi, a nie zwiększy koszty,

- odpowiedzialność kierownictwa,

- konieczność ciągłego i stałego udoskonalania,

- zaspokojenie potrzeb klienta w centrum zainteresowania,

- partnerstwo na linii kierownictwo - pracownicy,

- konieczność wprowadzania zmian w ramach kultury organizacji.

Podstawowym celem systemu TQM jest zapewnienie zadowolenia klientów organizacji (zewnętrznych i wewnętrznych) poprzez właściwe zarządzanie i doskonalenie realizowanych procesów. W ramach systemu zazwyczaj wyróżnia się trzy podstawowe elementy, stanowiące jego główne filary. Są nimi: zespoły, system oraz narzędzia.

W celu prawidłowego realizowania założeń systemu TQM konieczne jest zaangażowanie nie tylko ze strony kierownictwa, ale również wszystkich pracowników, którym zależeć będzie na doskonaleniu jakości i realizowaniu wymagań klientów. Praca w odpowiednio zorganizowanych zespołach powinna polegać na dążeniu do stałej poprawy jakości wytwarzanych produktów oraz usprawniania realizowanych procesów.

Globalizacja to bardzo złożone i szerokie zjawisko. Dokonuje się ona zarówno w sferze ekonomicznej, jak i w sferze społecznej. Postrzegana jest jako najbardziej fundamentalny proces zmian dokonujących się obecnie na świecie (Zorska 1998). Globalizacja przyczynia się do gwałtownych przemian otoczenia, w którym funkcjonują współczesne organizacje. W jej wyniku następuje narastanie konkurencji na rynkach światowych, gwałtowny postęp technologiczny, a coraz bardziej asertywni klienci oczekują najwyższej jakości produktów i usług.

Ogół tych przemian powoduje konieczność wdrażania nowych rozwiązań w obszarze zarządzania przedsiębiorstwem. Myśl przewodnia oznaczająca wychodzenie poza dotychczasowe ramy wyznacza główny kierunek wszelkich podejmowanych w przedsiębiorstwie działań. Zarządzanie organizacją w XXI wieku charakteryzuje się między innymi wielością i różnorodnością koncepcji i związanymi z nimi szczegółowymi metodami, technikami oraz narzędziami. Jak wcześniej wspomniano, są wśród nich koncepcje zorientowane na proces zarządzania, koncepcje zorientowane wyłącznie lub zdecydowanie na zarządzanie zmianami oraz takie, które zorientowane są na formy organizacji. 
Implementacja owych koncepcji zarządzania organizacją ma za zadanie zapewnienie przedsiębiorstwu przewagi konkurencyjnej na rynku. Należy jednak pamiętać, że nie zawsze zastosowanie określonej koncepcji daje spodziewane efekty. Nowe koncepcje zarządzania mają ogromną siłę przyciągania, ponieważ w dużej mierze upraszczają i porządkują sposób funkcjonowania organizacji. Niezbędna jest jednak ostrożność w doborze nowych rozwiązań, umiejętność wdrażania zmian oraz cierpliwość w sytuacji, gdy nie osiąga się natychmiastowych rezultatów.

\section{Literatura}

1. Czaja I., 2001, Globalizacja, globalizm, przedsiębiorczość - szanse i zagrożenia [w:] Globalizacja ISS, J. Klich (red.), Kraków.

2. Czerska J., 2002, Więcej niż odchudzanie, czyli istota koncepcji zarzadzania lean, „Personel”, grudzień.

3. Drucker P.F., 2000, Zarzadzanie w XXI wieku, Muza, Warszawa.

4. Giddens A., 1999, Runway World: The Reith Lectures revisited, http://www. Les. co. uk/.

5. Dziedzic D., Szymańska A.I., 2011, Marketing transakcji a marketing relacji, „Zeszyty Naukowe WSEI w Krakowie", nr 7.

6. Grupa Lizbońska, 1996, Granice konkurencji, Warszawa.

7. Hammer M., Champy J., 1996, Reengineering w przedsiębiorstwie, Neumann Management Institute, Warszawa.

8. Karaszewski R., 1999, Total Quality Management. Zarządzanie przez jakość. Wybrane zagadnienia, Tonik, Torun.

9. Karlöf B., Östblom K., 1995, Benchmarking - równaj do najlepszych, Warszawa.

10. Kempny M., 1998, Globalizacja [w:] Encyklopedia socjologii, Oficyna Naukowa, Warszawa.

11. Krawiec F., 2009, Nowa gospodarka i wizja lidera firmy XXI wieku, Difin, Warszawa.

12. Liberska B., 2001, Globalizacja - próba racjonalnego podejścia, „Nowe Życie Gospodarcze”, 28 stycznia.

13. Liberska B., 2002, Pojęcie $i$ definicje globalizacji [w:] Globalizacja. Mechanizmy $i$ wyzwania, B. Liberska (red.), PWE, Warszawa.

14. Lipiec J., 1996, Reengineering - nowa koncepcja zarzadzania?, „Ekonomika i Organizacja Przedsiębiorstwa".

15. Martyniak Z., 1996, Metody organizowania procesów pracy, Warszawa.

16. Martyniak Z., 1998, Nowe metody organizacji i zarządzania, Wyd. AE, Kraków.

17. Mittelman J., 1996, Globalization: Critical Reflection, Lynne Rienner, Boulder.

18. Nogalski B., Walentynowicz P., 2004, Nowoczesne koncepcje zarzadzania $w$ przedsiębiorstwach produkcyjnych regionu pomorskiego - próba oceny, „Zeszyty Naukowe Wyższej Szkoły Administracji i Biznesu w Gdyni”, nr 7, Gdynia.

19. Pawlak W.R, 2004, Od TQM do TQL w organizacji przyszłości, maszynopis rozprawy habilitacyjnej, ORGMASZ, Warszawa.

20. Penc J., 2002, Strategie zarzadzania, Agencja Wydawnicza PLACET, Warszawa.

21. Porter M.E., 1992, Strategia konkurencji, metody analizy sektorów i konkurentów, Państwowe Wydawnictwo Ekonomiczne, Warszawa.

22. Toffler A.H., 1996, Budowa nowej cywilizacji. Polityka trzeciej fali, Wyd. s.c., Poznań.

23. Toffler A., 2006, Trzecia fala, Wydawnictwo Kurpisz.

24. Trocki M., 2001, Outsourcing. Metoda restrukturyzacji działalności gospodarczej, PWE, Warszawa.

25. Zarządzanie przedsiębiorstwem przyszłości. Koncepcje, modele, metody, 2000, K. Perechuda (red.), Placet, Warszawa.

26. Zimniewicz K., 2009, Wspótczesne koncepcje i metody zarządzania, PWE, Warszawa.

27. Zorska A., 1998, Ku globalizacji? Przemiany $w$ korporacjach transnarodowych $i w$ gospodarce światowej, Wydawnictwo Naukowe PWN, Warszawa. 


\section{Globalisation and new concepts of corporate management}

Rapid globalisation of the economy, a revolution in the technical and information technology fields as well as a great variety of solutions provided nowadays by contemporary management makes the company management of XXI century to be predominantly concentrated on external environment of organization. This management should consist in defining the objectives of organisation in connection with the market needs and an individual customer. On the other hand, the economic, political and social processes taking place on a global scale force enterprises to also perform internal reorganisations.

Currently a number of various concepts of organisation management and detailed methods connected with them, techniques and tools, are applied in business activities. They can be divided into three groups:

- Concepts concentrated on organisation management process - marketing, logistics (just-in-time production and just-in-time management), human resources management, TQM total quality management, controlling, outsourcing, time based management (TBM),

- Concepts concentrated mainly on changes management - BPR business process reengineering, lean management,

- Concepts concentrated on organisation forms - learning organisation, intelligent organisation, network organisation, virtual organisation.

All these theories are distinguished by different attitudes towards organisation management and changes implementation. The managers and their ability to predict the results of the applied solutions are those who choose one particular concept or certain integrated attitude. 